\title{
Appreciating the Art and Science of Plastic and Reconstructive Surgery: A Year in Review
}

\author{
Jocelyn Graf
}

Medical Research Translation and English Editing, Proficia, Los Angeles, CA, USA

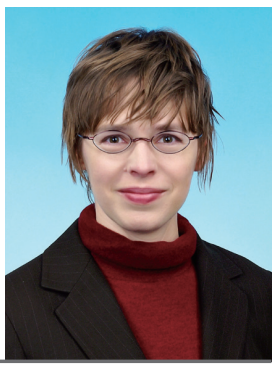

As the English proofreader for the Archives of Plastic Surgery (APS), I have had the opportunity to read each and every article that has been published in 2012. Although I have been reading medical research articles for many years, it has been my pleasure to become much more familiar with the field of plastic surgery in particular over these past months. As a layperson, I have been fascinated to learn what can be accomplished through plastic and reconstructive surgery. I have grown to understand that plastic surgeons combine art and science in a way that is unique among physicians, joining with nature to sculpt the human body: whether to renew a youthful appearance or to relieve a young child of a birth defect, whether to perform reconstruction after other surgical treatment or restore the body after an accident.

Before starting my work with APS, I had some misconceptions about plastic surgeons. I thought of their work as focusing only on appearances, and thus saw plastic surgery as superficial compared to other areas of medicine. However, it became clear to me through reading APS articles that maintaining and restoring physiology is as much or even more important in plastic and reconstructive surgery, and that it is a major challenge to keep tissue alive and growing after it has been modified or even moved to another location on the body.

Furthermore, the communications pieces in APS on working with children and doing volunteer work revealed yet another facet of a plastic surgeon's job: to care for the patient's emotional needs and psychological well-being, as the process of reshaping the body can strongly affect the mind and even the sense of self.

Given all the factors that can impinge on the success of an operation, plastic surgeons must stay up to date with the latest research findings in order to choose the technique that is most likely to be successful for a given patient. In fact, APS is itself contributing to the global accessibility of such information by providing one of the highest profile sources of open access clinical research articles in the field. Anyone-researchers, clinicians, even patients and their families-may find current and relevant information on plastic surgery techniques and outcomes through free access to all APS articles on its website. Phone apps for accessing the information on Android and iPhone are also coming soon.

As the first year of the publication of APS in English draws to a close, congratulations to all who have contributed to its success are in order. I would like to offer my thanks to the Editorial Board and all the reviewers who have given of their time and expertise to ensure that the articles published in APS are of the highest quality. In particular, the Editor-in-Chief, Jeong Tae Kim, and Associate Editor, Jang Hyun Lee, with whom I have worked closely to guide each author through the review and revision process, deserve special appreciation for the energy that they have devoted to making the major transition to an English language format possible. Similarly, the work of each author who has submitted a paper should be acknowledged. Although it might not seem very significant to write a travel report for the communications section or submit a photo of an interesting case, all of these contributions together are raising the international profile of the clinical practice of plastic surgery in the Asia-Pacific region.

As we move into 2013, it is time to take APS into the next phase, by building more international connections among readers and authors. I hope that each reader forwards a link from an interesting article in APS to a colleague to spread the word

Copyright $(\odot 2013$ The Korean Society of Plastic and Reconstructive Surgeons

This is an Open Access article distributed under the terms of the Creative Commons Attribution Non-Commercial License (http://creativecommons.org/

licenses/by-nc/3.0/) which permits unrestricted non-commercial use, distribution, and reproduction in any medium, provided the original work is properly cited.

www.e-aps.org 
about APS. Just as importantly, I hope each APS contributor invites a colleague based in another country to submit an article and take advantage of the broad exposure made possible by open online access. I am looking forward to reading the articles that you and your colleagues submit in 2013.
Correspondence: Jocelyn Graf

Medical Research Translation and English Editing, Proficia, 4671 Hollywood Blvd., Los Angeles, CA,

USA

Tel: +1-213-718-7301, E-mail: jocelyngraf@gmail.com

No potential conflict of interest relevant to this article was reported.

Received: 4 Dec 2012 • Revised: 6 Dec 2012 • Accepted: 7 Dec 2012

pISSN: 2234-6163・ elSSN: 2234-6171

http://dx.doi.org/10.5999/aps.2013.40.1.1 • Arch Plast Surg 2013;40:1-2 